\title{
PROPOSITIONAL OBJECTS*
}

W. V. QUINE

Harvard University

A declarative sentence is usually true or false. But your typical declarative sentence is not fixedly true or false. It is true on one occasion and false on another, because of the tenses of its verbs and the varying references of its pronouns or demonstrative adverbs or other indicator words. By incorporating additional information into the sentence, such as dates and the names of persons and places, we can obtain an eternal sentence: one that is fixedly true or false. Thus an eternal sentence need not be a law of mathematics or of nature; it can also be a report of a passing event.

Now a proposition is the meaning of a sentence. More precisely, since propositions are supposed to be true or false once and for all, a proposition is the meaning of an eternal sentence. More precisely still, it is the cognitive meaning of an eternal sentence; that is, just so much of the meaning as affects the truth value of the sentence and not its poetic quality or its affective tone.

Not that this is precise. The word 'meaning' survives in my explanation, and it covers a multitude of sins. When I explain propositions as the cognitive meanings of eternal sentences I am merely telling you which of various unsa. tisfactory notions it is that I am going to be worrying about.

I shall speak of why the notion of proposition or something like it seems to be wanted, and I shall speak of obstacles to rendering it satisfactory. Also I shall bring up other notions somewhat akin to that of proposition, and consider

* A lecture given at the University of Michigan, the University of Chicago, the University of Illinois, and Amherst College in the spring of 1965. 
whether these might do some of the work for which propositions had been wanted. It is because of these other notions that instead of giving my subject simply as "Propositions" I have given it yet more vaguely as "Propositional objects." I mean the term to apply to any of the things that might be proposed as meanings of sentences or as objects of the propositional attitudes.

The trouble with propositions, as the cognitive meanings of eternal sentences, is individuation. Given two eternal sentences, themselves visibly different as linguistic forms, it is not sufficiently clear under what circumstances to say that they mean the same proposition. It is on this score that the sentences are less dubious entities than the propositions.

L. J. Cohen sees matters differently. ${ }^{1} \mathrm{He}$ is prepared to accept meanings in one or another sense to play propositional roles, but he is not prepared to recognize eternal sentences for them to be meanings of. "No language-sentence whatever can be relied on to maintain its truthvalue invariant under all circumstances", he writes ( $p$. 232 ). What he is worried about is semantic change in language from time to time or from speaker to speaker. We cannot disallow this factor by stipulating that sameness of language is intended, because, he says, when word forms are the same, there is no saying what to count as doctrinal disagreement and what to count as linguistic disagreement.

Now I can sympathize with this remark, but let us see just how it bears on the notion of eternal sentence. It bears certainly on whether a sentence can be relied on to remain accepted as true. A man may change his verdict, and we may not know whether to account this a change of language in the given case. But truth value is not verdict. The semantics of truth is linked to verbal behavior only less directly. When a man changes his verdict on an eternal sentence, now denying it, say, the significant thing is that he will hold also that the sentence always was really false;

1 L. J. Cohen, The Diversity of Meaning. London, 1962. 
he will not say that his earlier verdict was right too and this is just a different case. He may say he has changed his mind, or he may doubt having made the earlier verdict, or he may say he has changed his language, that is, that he is using a word differently.

The subtlety of the matter can be brought out by reflecting that a sentence may even be an eternal sentence for a speaker at one time and not at another. Maybe someone can devise a natural example of this. It would have to be a case of linguistic change. And it would still be right to say of the sentence, on the earlier occasion, that it is true forever or false forever. Qua sentence of that language, of course.

Cohen could rightly say, then, that whether a sentence is eternal depends on what language you are thinking of it as a sentence of. If there is a language in which the form of words 'It is raining' means 'Iron is a metal', then 'It is raining' is an eternal sentence for that language and not for English. But this brand of relativity applies to mere truth as well as to eternality. We all know that truth values, applied to sentences, depend on a language parameter; a sentence may by phonetic accident be true here and now as a sentence of one language and false here and now as a sentence of another. The notion of an eternal sentence is only as badly off as the notion of a sentence's being true here and now. But this, I must say, is bad enough. I dislike imagining a tacit subscript on the word 'true', or 'eternal', specifying the language. A trouble with the notion of a language is that it, like the very notion of proposition or meaning that I have complained about, has been given no satisfactory principle of individuation.

One use that has been made of propositions, in order to dodge the relativity to language, is as truth vehicles: propositions, it is said, and not sentences, are what are true or false. But is seems exorbitant to posit propositions for this purpose. Being true or false does not depend on how propositions are individuated, after all, and yet the notion 
of proposition itself does. In $W$ ord and Object (p. 208), consequently, I favored taking the eternal sentences themselves as the truth vehicles. They are better than other sentences, at any rate, as being true or false independently of time, place, sspeaker, and the like. But they are as bad as other sentences in admitting of variation in truth value from one language to another.

To resort to propositions for the purpose of truth vehicles does not solve the problem, however; it merely gives up on it.

Another alternative to consider, as truth vehicle, is the concrete event of utterance. I wonder whether we can agree that no such event is bilingual, even when the speaker is bilingual and the form of words belongs by coincidence to both his languages and has opposite truth values in the two. It may be felt that to concede this is to assume covertly an unanalyzed distinction between meanings in the speaker's mind, and that we could as well accept those meanings as propositions and be done with it. At any rate Scheffler has used utterance events, not as truth vehicles but as objects of propositional attitudes, in the belief that he thus avoided the language-identification problem: ${ }^{2}$

I suppose the thing to do is to look upon that infinitely rare bilingual coincidence simply as an ambiguous utterance. So the plan I now propose is to take as truth vehicles not eternal sentences but eternal-sentence utterance events: utterances of sentences that are eternal sentences for the utterer at the time; or, to revert to language, utterances of sentences that are eternal sentences of the language that the utterer is speaking at the time.

But utterance events present a new difficulty as truth vehicles: the difficulty that only a finite and therefore infinitesimal proportion of our sentences ever get uttered, even if we count writing as uttering. Such laws as that any two falsehoods form a false alternation, and any two truths

2 Israel Scheffler, "An inscriptional approach to indirect quotation", Analysis 14 (1954), pp. 83-90. 
form a true conjunction, become hard to construe if the existence of utterances matters. We would seem driven at that point to contrary-to-fact conditionals, and thus out of the frying pan into the fire. It is a difficulty that did not arise as long as we talked of sentences, linguistic forms rather than of utterance events, because a sentence can be thought of as simply the sequence, not in the historical but in the mathematical sense, of its successive letters or phonemes. Sentences in this sense will always exist, regardless of utterance, and not vacuously as the null class, either, if we allow a modicum of set theory.

What, then, to do about utterance events as truth vehicles? I have two ideas. The first one is that we explain existing logical theory as a convenient schematism that can be applied to give right results when suitable existence conditions in respect of utterances happen to be met. This idea would take some working out. The second idea is that we let the truth vehicles be the eternal sentences after all, as they were in Word and Object, and then just find a way of tolerating the tacit dependence of truth and eternality upon a language parameter.

I suggest that we assign to that parameter, as its value, the language that the speaker is speaking when his tacit use of the parameter takes place. This ego-directed parameter does not really raise the general problem of individuation of languages, though my use of the word 'language' would seem to raise it. For it is enough that the speaker's own total present speech dispositions be taken as the value of the parameter.

Dispositions. Out of the frying pan into the fire again? I think not. We are always involved in talk of dispositions, even in the most empirical studies of speech behavior and of natural phenomena generally. A disposition to do a certain thing when stimulated in a certain way is a mechanism, already mechanically understood or not, in the organism; and the name of the disposition tells us how to gather evidence of varying conclusiveness for its presence. 
We cannot gather much evidence at a given moment for a speaker's range of speech dispositions at that moment, true. But we can gather, for his dispositions at a moment, much evidence at other moments: indirect evidence from which we reason according to plausible psychological theories and generalizations regarding the persistence of habits and other matters.

So much for propositions as truth vehicles. Now another purpose for which propositions have long been thought to be needed is as objects of the propositional attitudes of believing, wishing, striving, regretting, and the like. Here the individuation problem is acute. We quote a man's pre. viously enunciated belief. in our own words; what changes of phrasing will have made a different belief of it, perhaps falsifying our imputation of it to him? Here an overfine individuation would do no harm; we would merely get excessively discriminated beliefs moving in bundles. But an over-coarse individuation would be harmful. As for other contexts, some are sensitive in both directions. For instance, suppose I say I have given up precisely three beliefs since lunch. An over-coarse individuation could reduce the number to two, and an over-fine one could raise it to four.

It is conceivable, for that matter, that different principles of individuation, hence different senses of 'proposition', might be wanted for different propositional attitudes. An individuation of propositions that is proposed in some philosophical connections makes sentences mean identical propositions when and only when the biconditional of the sentences is analytic; and this does seem to be too coarse an individuation for the purposes of a theory of belief. But I am speaking impressionistically, for there is not to my knowledge an acceptably clear notion of analyticity, let alone an individuation of beliefs.

A discouraging thing about the propositional attitudes is that the very obstacles to a satisfactory individuation of their objects are obstacles also to a clear interpretation of 
the idioms of propositional attitude even apart from their objects. Thus take belief. If I repudiate beliefs as objects, $\mathrm{I}$ give up saying things like ' $\mathrm{I}$ have stopped believing something (or three) since lunch.' I can still profess and impute beliefs explicitly, one by one. I can still say that I believe that the faces of the Great Pyramid are equilateral; this I can say even though denying that there are any such things as that the faces of the pyramid are equilateral, along with there being such things as I and the pyramid and its faces. But in repudiating beliefs as objects what do I gain? The problem whether, in believing the faces equilateral, I ipso facto believe them equiangular, is of a piece with the individuation problem and it is still there to confront us when the beliefs as objects are dropped.

In Word and Object (p. 218) I suggest that the ques. tion how far we can rephrase a belief, and not lose the right to impute it, depends on our purpose in imputing it. Correspondingly for propositional attitudes other than belief. This being the case, there is no hope of a general translation of the idioms of propositional attitude into other and more objective terms. In each particular case, knowing the circumstances, we may be able to say something in other terms that would be no less useful as an aid to transacting some business in hand; but we can hope for no verbal equivalent of ' $a$ believes that $p$ ', even for given ' $a$ ' and ' $p$ ', that is independent of the circumstances under which it may have been said that $a$ believes that $p$. The situation is like that of indicator words: You cannot eliminate indicator words by paraphrasing a sentence without regard to the date or other circumstances of its utterance. So in Word and Object (p. 221) I left the idioms of propositional attitude in a second-grade status, along with the indicator words: the status of useful vernacular having no place in the austere apparatus of scientific theory.

I think none of us is uncomfortable about relegating the indicator words to that status, despite their utility. We 
understand both why they are useful and why they would bring no enrichment to the vocabulary of scientific law. We can foresee how in each particular situation we would set about circumventing an indicator word. Over relegating the idioms of propositional attitude, however, one is less comfortable. One has a sense of genuine loss.

We like to say for instance that the cat wants to get on to the roof, or is afraid the dog will hurt him. In so saying we purport to relate the cat perhaps to a state of affairs. The cat wants, or fears, the state of affairs. His wanting or fearing is a strictly physiological affair, granted, and our evidence for it is our observation of the cat's overt behavior. But the particular range of possible physiological states, each of which would count as a case of wanting to get on to that particular roof, is a gerrymandered range of states that could surely not be encapsulated in any manageable anatomical description even if we knew all about cats. Again the range of possible sequences of overt behavior, each of which would count as evidence of wanting to get on to that particular roof, is a gerrymandered range that cannot be encapsulated in any compact behavioral description. Relations to states of affairs, such relations as wanting and fearing, afford some very special and seemingly indispensable ways of grouping events in the natural world.

Our philosophical difficulties over them have perhaps arisen in part from the sentential bias of our idioms of propositional attitude. These idioms all follow the pattern of indirect quotation, and so involve us in the problem of limits of allowable variation of the subordinate sentence. Such a textual problem seems ludicrously irrelevant when we come to dumb animals; what the cat wants is a simple matter of superposition with respect to the roof, by whatever name. Can we perhaps accommodate some primitive cases, at least, of the propositional attitudes by talking of states of affairs, in some sense of the term very unlike the idea of proposition or of sentence? 
Let us begin by thinking of a state of affairs as a class of possible worlds: the class of all the possible worlds in which, intuitively speaking, that state of affairs would be realized. What then is a possible world? To simplify matters let us accept for a while an old-fashioned physics in which, as Democritus held, the atoms are homogeneous in substance and differ only in size, shape, position, and motion. Let us suppose further that space is Euclidean.

Now when this much is granted, there remain for each point in space just two possible states: the point may lie within some particle or it may be empty. Each distribution of these states over all the points of space may be seen, not yet quite as a possible world, but as a possible momentary world-state.

It is somewhat as if we were taking possible world states as state descriptions in Carnap's sense, and taking our sole predicate as the predicate 'occupied', and taking our individual constants as the names of the points of space. But this is not quite it. One objection to state descriptions is that each individual would have to have a name. Our individuals are here the points of space, and we know that they are not all nameable, since they are indenumerable while names are denumerable. The virtue of taking a possible world state as an exhaustive assignment of 'occupied' or 'empty', 'yes' or 'no', to points of space, is that the assignment does not have to be seen as a state description; it does not have to be verbal. It can simply be identified with the aggregate of the occupied points themselves. Each portion of space, big or little, compact or scattered, may thus be accounted a possible world state. Realization of that world state would consist in there being matter at each of those points of space and none elsewhere.

What are points, though, and what is space? Would we be committed to two sorts of individuals, namely points of space and portions of matter? No, we can bypass the points by adopting a system of coordinates and speaking of triples of real numbers. Our ontology then requires only 
portions of matter, as individuals, and the usual superstructure of classes of individuals, classes of such classes, and so on. The real numbers find their place in the third or fourth story of this edifice, as is well known.

On this approach, a possible world state becomes simply any class of triples of real numbers. To any such class we equate what, intuitively, would be called the possible world state having matter at all and only the positions given by number triples in the class.

I passed over a compelling reason for shifting from points to number triples. There is the desire for ontological economy; there is the puzzle over just what a point might otherwise be; but also, and more compellingly, there is the relativity of position. Unless we are prepared to believe that absolute position makes sense, the very idea of a point as an entity in its own right must be rejected as not merely mysterious but absurd. And notice that I am not speaking of Einstein's relativity here; I am speaking of Leibniz's.

Actually a problem of relativity of position is still with us when we give up the points in favor of the number triples. The assigning of numbers depends on an arbitrary choice of coordinates; this would be arbitrary even if position itself were absolute. A possible world state should continue to be the same possible world state when we shift or rotate the coordinate axes; yet this changes the number triples.

The version of a possible world state as a class of number triples is thus still in trouble. But we can rise above the trouble by ascending one more level and taking a possible world state rather as a class of classes of number triples. Instead of taking it as a particular class $C$ of triples we take it as the class of all the classes into which $C$ could be carried by translation and rotation of coordinate axes. Described figuratively in terms of points again instead of triples, what has happened is that instead of taking a 
possible world state as a point set we are taking it as the class of all point sets congruent to a given point set.

We have thus risen above the arbitrariness of position and orientation of coordinate axes. That much, I remarked, would have been arbitrary even if position itself were absolute. But note now that our correction has in fact achieved the desired relativity on both counts. In abstracting from differences of coordinate axes it leaves no way whereby we could mark absolute positions if we wanted to. Happily we do not want to. If we believed in absolute space we should have had, perhaps, to accept some still admittedly arbitrary system of coordinates to go with it.

As it is, our new possible world states are free of all taint of absolute place and of arbitrary coordinates. Arbitrariness, even so, remains in another quarter: the arbitrariness of the units for measuring distance. Switching from feet to inches has the effect of multiplying all the numbers in our number triples by twelve, and so changing our possible world state to another, if a possible world state is a class of classes of number triples as last conceived; and this is intolerable, since surely a possible world state should not really be changed by describing it in inches instead or feet.

We eliminated the previous arbitrariness by taking a possible world state not as a class of triples $C$, but as the class of all the classes into which $C$ could be converted by changing the axes. Now we can eliminate the arbitrariness of unit by further generalization, taking a possible world state as the class of all classes into which a class $C$ of triples can be converted by changing the axes and multiplying all numbers by a constant. In geometrical language, we are now taking a possible world state as the class of all the point sets that are geometrically similar to a given point set; we settle for mere similarity now instead of congruence.

The previous and lesser step of abstraction, which looked to congruence, was seen to eliminate not only the arbitrariness of axes but also any trace of absolute position. 
Of this we were glad. Now similarly this new step of abstraction eliminates not only the arbitrariness of units of maesure but also any trace of absolute size. Have we now gone too far? If size is absolute, if it makes sense to speak of a world in which all things are twice as big and twice as far apart as they are in ours, then we have thrown away too much. We have provided for uniform change of all numbers without change of world state; in so doing we made the choice of units immaterial, as desired, but we made absolute size immaterial also apart from units. If this is undesirable, we must perhaps go back and allow some admittedly arbitrary unit of measure after all.

But I am inclined to welcome relativity of size, or distance, as well as that of position. Grant, for instance, that absolute mass plays a role in the actual laws of physics which absolute position does not; still we could declare everywhere a uniform change in absolute mass by making a systematic compensatory change in the laws themselves. The combined maneuver is still of the empty verbal kind that we like to regard as carrying a possible world state only into itself.

Very well, then: a possible world state is any class whose members are all the classes that are geometrically similar to some one class of number triples. For brevity I apply the geometrical predicate directly to the class of number triples; the proper algebraic meaning of it can of course be spelled out.

A possible world, finally can be explained in somewhat the same way but with four dimensions, representing spacetime. A possible world becomes, roughly, any class whose members are all the classes that are geometrically similar to some one class of number quadruples. But not quite. In one way this is too broad, in another too narrow. It is too broad in that whereas we wanted in the three-dimensional case to allow all rotations of axes, in the four-dimensional case we want the fourth axis, time, to stay untilted. For remember that we are still in pre-Einstein 
space-time. And it is too narrow in that whereas we wanted in the three-dimensional case to allow all numbers to be changed only by a constant factor, in the four-dimensional case we are content to let the fourth or time coordinate be multiplied by a factor different from that of the other coordinates. The point here is that, being still in preEinstein space-time, we are indifferent as to how many feet in space be geometrically equated to a second in time. In short, in passing from the account of possible world states in three dimensions to the account of possible worlds in four dimensions we modify the geometrical-similarity stipulation in these two ways: we strengthen it by requiring that things preserve their polarization with respect to the fourth dimension, and we relax it by permitting a uniform stretching in the fourth dimension.

This explication of possible worlds is predicated on the view that every possible world has homogeneous matter, Euclidean space, and a time dimension independent of frame of reference. These traits, being then traits of all possible worlds, rate as necessary. The view is debatable, since the real world is believed to lack all three traits.

One thing good about this version of possible worlds, nevertheless, is that it stays within a clear extensional ontology. I expect that while still staying within these terms we could complicate it to suit current physics. We might devise a version compatible with current physics and incompatible with worlds of the foregoing sort, or, what would be more difficult still, we might arrive at a version sufficiently broad and neutral to cover the lot. Either outcome would represent a particular decision as to what to count as possible, in an extra-logical and somewhat arbitrary sense of the term. But meanwhile I think it will be little strain on our imaginations to imagine that the facts of physics are of the homelier sort to which my detailed version of possible worlds was directed. This is a version that we can easily keep in mind, and it will be no less 
relevant to the further points I want to make than a more sophisticated version would be.

What the cat wants, then, is the state of affairs that is the class of all possible worlds in which he is on that roof. What he fears is the class of all possible worlds in which the dog has him. What I believe is the class of all possible worlds in which the Great Pyramid has equilateral faces. Another thing I believe is the class of all possible worlds in which Cicero denounced Catiline.

The matter of individuation that had worried us in propositions is satisfactorily settled for states of affairs. The worlds in which the pyramid's faces are equilateral are indeed the worlds in which they are equiangular; not an atom is discrepant. However, there are new troubles. How is Catiline to be identified in the various possible worlds? Must he have been named 'Catiline' in each, in order to qualify? How much can his life differ from the real life of Catiline without his ceasing to be our Catiline and hav. ing to be seen as another man of that name? Or again, how much can the pyramid differ from the real one? It will have to differ a little in shape, if my belief about it happens in fact to be mistaken. Is it sufficient, for its identification in other worlds, that it have been built by Cheops? How much then can his life differ from the real life of Cheops without his ceasing to be our Cheops?

Even the cat cases are troublesome. In a possible world with many similar cats and dogs and roofs, which cat is to be he? One of these possible worlds will have a cat like him on a roof like his, and another cat like him in the dog's jaws; does it belong to both the desired state of affairs and the feared one?

The cat examples suggest that in abstracting from the particular placement of coordinate axes $I$ went too far. Perhaps we should keep the origin fixed, thus allowing rotation of axes but no shifting of them. The entertainer of the propositional attitude can then be identified as the organism at the origin. This will not take care of the $\mathrm{Ci}$. 
cero-Catiline example nor the pyramid example, but it will take care of the cat examples. Each of the possible worlds suited to the cat examples will have its center or origin in the midst of a cat - say at the center of gravity of the cat's pineal gland. The cat will not stay at the spatial origin through all time; that is, he will not cling always to the time axis; but he will be at the spatial origin at time 0 , and that will identify him as the cat in the attitude.

What we have now are what we may call centered states of affairs. Each is a class of centered possible worlds. Each centered possible world is the class of all the classes of number quadruples that can be got from some one class of number quadruples by multiplying the first three numbers by a constant factor, multiplying the fourth number by a perhaps different constant, and performing the operations that correspond to a rotation of the first three axes. Notice that the time axis stays fixed now; for it was to stay untilted before, and we have now disallowed the shifting of any axes.

So I am suggesting that the objects of propositional attitudes may in some primitive cases, such as the cat examples, be taken as centered states of affairs. This does not cover selfless examples such as the beliefs about Cicero and the pyramid, and whether it may help to open a line of approach to them I cannot say. At any rate the egocentric propositional attitudes, those of wishing or hoping or fearing or trying or expecting to be in some sort of physical situation, seem to be the most primitive ones; and they are covered. Perhaps these are the only ones that a dumb animal can reasonably be said to entertain; I expect the others presuppose language.

If we are to deal only with the egocentric propositional attitudes, however, it would seem that even these centered states of affairs take in a lot of unnecessary territory. If the human or feline animal under consideration is attitudinizing strictly about what might hit him, then, instead of 
taking account of all the possibilities of occupiedness and emptiness on the part of all the points of space-time, we could as well limit our attention to the surface of our selfcentered animal and take account merely of the possibilities of activation and inactivation of its several nerve endings. The possibilities, in short, of sensory input. We can limit our attention to the organism, letting the rest of the world go its way, and the organism will be none the wiser. Save the surface and you save all. Activate its surface, scratch its back, and the organism will ask no more.

Instead therefore of a cosmic distribution of binary choices (occupied vs. empty) over the points of space-time, what we have to consider is a distribution of binary choices (activated vs. quiescent) over the sensory receptors of our target animal. Each such distribution is a possible world in our new sense - or, as we may better entitle it, a stimulation pattern. Then, instead of taking as object of the propositional attitude a state of affairs in the sense of the range of possible worlds that show the cat on the roof, we can take as object the range of stimulation patterns that go with his being on the roof. Patterns of stimulation of the cat himself.

A range of possible worlds was a state of affairs. What now is a range of stimulation patterns? It is what I called, in Word and Object, an affirmative stimulus meaning; or let us just say now a stimulus meaning. In $W$ ord and $O b$ ject I talked of stimulus meanings of occasion sentences; the stimulus meaning of 'It's raining' is the range of stimulation patterns that would prompt a speaker of the language to assent to 'It's raining' if asked. And now these same stimulus meanings - these same ranges of stimulation patterns, though not necessarily allocated to sentences- have turned up as objects of the egocentric propositional attitudes for cats and others.

I like this effect of linking species. After all, the association of an observation sentence with a stimulus meaning is the most primitive phase of language. It is what the 
infant accomplishes first, in the course of acquiring language, and it is perforce the field linguist's entering wedge into radical translation. Stimulus meanings are there for sentences to mean, some of them, when sentences happen along, and they are there also as objects for the egocentric propositional attitudes, be the attitudinists human or feline. I do not offer any theory of mental imagery, applicable to cats or to people. It is just that I am cheered by the hint, however slight, of a common treatment.

See also that we are brought around to something reminiscent of an earlier phase in our considerations. Propositions were thought of as meanings of sentences, and also as the objects of the propositional attitudes. And now here are our stimulus meanings, functioning both as the meanings of some sentences and as the objetcs of some propositional attitudes. However, stimulus meanings are remote as can be from propositions in the sense of meanings of eternal sentences. They are meanings, on a reasonable usage of 'meaning', only of observation sentences.

Whatever may have been felt about relegating idioms of propositional attitude to a status of second-rate vernacular, we may be sure that some notion of stimulus meaning is needed at the austerest scientific level. If stimulus meanings are good objects for primitive propositional attitudes, then primitive propositional attitudes are assured at last of their objects. For obviously any treatment of language as a natural phenomenon must start with the recognition that certain utterances are keyed to ranges of sensory stimulation pattern; and these ranges are what the stimulus meanings are.

And yet there is, in the detail of the underlying notion of stimulation pattern, a cause for worry. It seems vital that in correlating one subject's verbal behavior with another's, for instance as a basis for translating one language into another, we be able to equate one subject's stimulations to another's. Yet how are we to do so? If we construe stimulation patterns my way, we cannot equate them 
without supposing homology of receptors; and this is absurd, not only because full homology is implausible, but because it surely ought not to matter.

The problem is stubborn even in computer theory. What does it mean to say that two machines are given the same input? I am speaking here not of a sharing of the input energy, of course, but of full similarity of the two input events for the two machines, where the machines differ. Say we send sixty volts into each machine; does this mean sameness of input? What if in the one machine the first effect of the electricity is to start a motor, and in the other its first effect is to sensitize a photoelectric eye? The question is, in part, how far to pursue the input into the machine and still call it input. And surely there is no answer. In practice we define input for a particular machine in such a way as to simplify our theory of programming that machine; and then we can say what constitutes sameness of input for machines of that model, and not much beyond.

What psychologists have said about stimulation has mostly either been independent of any equating of stimulation from subject to subject, or has involved the equating only of some specific stimulations without raising the general problem. It is when we turn to language theory that the problem becomes acute. Being social, language depends on associating utterances with stimulations that can be publicly identified in their recurrences from occasion to occasion and speaker to speaker.

It is the stimulation at the bodily surface that counts, and not just the objective existence of objects of reference off in the distance, nor yet the events deep inside the body. Even a primitive mother, in encouraging or discouraging a child's use of a word on a given occasion, will consider whether the relevant object is visible from where the child sits. And even a highly civilized mother is content, when checking the child's testimony against the child's data, not to penetrate the child's surface. The bodily sur- 
face would thus seem to be, for an activity ever subject to social adjustment as language is, the best boundary at which to define input. And yet, when we come to the seemingly essential business of saying what it is for two people to be stimulated alike, we tangle with the myth of homologous nerve endings. What will we do when we get to Mars? Just because we and the Martians cannot match up nerve endings, must we despair of relating our languages?

There is and odd irony here. We had been worrying whether scientific sense could be made of mentalistic idioms of propositional attitude, and now we seem unable even to negotiate the A-B-C's of behavioristic psychology; we are stopped by the notion of a stimulus.

The trouble is really, of course, the intersubjective equating of stimulations. I see no fault in defining the sensory stimulation of a person at a time as the triggering, at that time, of all of a subclass of his sensory receptors. I see no fault, either, in defining a pattern of stimulation of that person simply as a subclass of his sensory receptors; realization of the pattern is then the stimulation that consists in activating all and only the receptors in that subclass. When it comes to the intersubjective, however, perhaps the most we can realistically speak of is resemblance and not identity of stimulation patterns. All stimulation patterns should perhaps be viewed as peculiar to individual subjects, and as bearing intersubjective resemblances, at best, based on approximate homologies of nerve endings. Perhaps the relation of intersubjective stimulus synonymy of observation sentences could be redefined in terms of resemblance rather than identity of stimulus meanings, and finally in terms of near-homology of nerve endings. But this certainly seems a long way around.

All such homology considerations are glaringly theoretical. In practice we usually assure adequately similar stimulation of two subjects by seeing to it that their bodies are reached by similar barrages of outside forces and that the subjects are oriented alike to the stimulus sources and, 
perhaps, that their eyes are open. On these terms we can even compare a man and a Martian, with never a thought of homologies beyond what little may be required in order to settle on the proper way of orienting the Martian to the stimulus sources.

The Martian might indeed make trouble for us by reacting to forces to which the man is unresponsive and vice versa. The triggering of a receptor is what counts, and this is why the equating of stimulations for two subjects persists in raising homology considerations when we try for an explicit theory. Our rough and ready procedure of simply giving our two subjects similar orientation to similar power sources works well in practice, and for this we can be grateful. It works well because of the anatomical resemblance of people. But for these similarities language itself might not have been propagated.

I leave you, therefore, with a problem of theoretical formulation that carries no evident practical problems with it. It is the problem of saying in general what it means for two subjects to get the same stimulation, or, failing that, what it means for two subjects to get more nearly the same stimulation than two others. 
RESUMEN

Llamamos oración eterna a la oración declarativa que tiene siempre el mismo valor de verdad. La proposición puede definirse como el significado cognoscitivo de una oración eterna. Aquí se discute esta definición y se proponen otras nociones que puedan cumplir las tareas para las que se necesitaba a la proposición. De aquí que el artículo se titule "Objetos Proposicionales" y no "Proposiciones" solamente.

El probleına de definir así las proposiciones es el de que dadas dos oraciones eternas de forma lingưística distinta no queda suficientemente claro en qué circunstancias significan la misma proposición. Las oraciones son, en este sentido, entidades menos dudosas que las proposiciones. L. J. Cohen tiene otra objeción: no piensa que pueda aceptarse esa definición debido al hecho de que las oraciones pueden cambiar de significado, y a que, por ello, no hay oraciones estrictamente eternas. Es conveniente recordar, sin embargo, que cuando el veredicto de una persona acerca de una oración cambia, aunque esto se deba a un cambio en el significado de la oración, esa persona dirá que en realidad ha sido siempre falsa. La sutileza del asunto se muestra cuando reflexionamos en el hecho de que una oración puede aún ser considerada eterna por un hablante en un momento determinado y dejar de serlo para el mismo en otro. La oración es considerada verdadera o falsa para siempre. Qua oración de determinado lenguaje, por supuesto. Cohen pudiera decir con justeza que la eternidad de una oración depende del lenguaje al que pertenezca. Si hay un lenguaje en el que 'llueve' signifique 'el hierro es un metal', entonces 'llueve' será en ese lenguaje una oración eterna y no lo será en español. Pero no sólo la eter. nidad depende de ese parámetro lingüístico, lo mismo sucede con la simple verdad o falsedad. Pero esto no parece muy bueno. Me disgusta imaginar un indice tácito que especifique un lenguaje en todo uso de las palabras 'verdad' o 'eterna'. El problema de este parámetro lingüístico es, además, que no se ha logrado tampoco para 'lenguaje' un principio adecuado de individuación.

Con objeto de evitar la relatividad al lenguaje, se ha intentado introducir la proposición como vehículo de los valores de verdad. Las proposiciones y no las oraciones son verdaderas o falsas. Parece excesivo, empero, postular proposiciones con tal propósito. Su valor de verdad no depende de cómo individuemos a las proposiciones, la noción de proposición, en cambio, sí depende del principio que usemos para hacerlo. Es por esta razón que me incliné en Word 
and Object por las oraciones eternas como los vehículos de la verdad. Son éstas mejores que las demás oraciones por tener valor de verdad fijo, con independencia de tiempo, lugar, persona que las profiere, etc. Pero tan malas como las demás por admitir variación de su valor de verdad de un lenguaje a otro. Otra alternativa para los vehículos de la verdad es el evento concreto del proferimiento. $\mathrm{Si}$ un evento tal fuese bilingüe, porque la oración perteneciera a dos lenguajes que el hablante usase indistintamente, bastaría considerarlo ambiguo, para que no hubiera problema a este respecto. Propongo, entonces, que se tome como vehículo de la verdad al evento de proferir una oración eterna, o, para volver al lenguaje, al proferimiento de oraciones que son eternas en el lenguaje que el proferente habla en ese momento.

Pero tomar a los eventos de proferimiento como los vehículos de la verdad presenta otro problema. Se complica la construcción de leyes como la de que dos falsedades forman una alternativa falsa, debido a que sólo una proporción infinitesimal de nuestras oraciones se llega a proferir. Y aquí incluímos las escritas.

Pero entonces ¿qué puede hacerse con los eventos de proferimiento como vehículos de verdad? Tengo dos ideas: La primera es explicar la teoría lógica existente como un esquematismo aplicable a proferimientos que se den bajo condiciones adecuadas de existencia. La segunda es continuar con las oraciones eternas para vehículos de verdad y resolver el problema de su dependencia a un parámetro lingüístico. Sugiero que, con este objeto, asignemos como valor del parámetro el total de las disposiciones lingüísticas presentes en el parlante. Introducir disposiciones no es problema insoluble. Una disposición es, en cierto modo, un mecanismo. Y si bien no puede descubrirse en un instante dado cuáles son las disposiciones lingüísticas de un sujeto, es posible hacerlo tomando otros momentos. Se trata de pruebas indirectas desde las que razonamos de acuerdo con teorías y generalizaciones psicológicas acerca de la persistencia de hábitos y de otras materias.

Otro propósito para introducir proposiciones es la necesidad de objetos de las actitudes proposicionales como creer, desear, etc. Aquí el problema de individuación es agudo. Cuando citamos la creencia de otro en nuestras propias palabras ¿qué cambios en la expresión la convertirán en otra creencia? En este caso si la individuación peca de fina no hay problema, pero en otros ejemplos podría volver falsa una afirmación. Tal es el caso cuando decimos haber abandonado tres creencias desde el medio día. Una individuación demasiado burda las podría reducir a dos, una demasiado fina las aumentaría a cuatro, por ejemplo. No sería, pues, extraño que diferentes principios de individuación, y con ello diferentes 
sentidos de 'proposición', pudieran convenir a diferentes actitudes proposicionales.

De nada serviría negar la existencia de objetos de las actitudes proposicionales. Las dificultades para individuarlos serían ahora obstáculos para una clara interpretación de las expresiones de actitudes proposicionales. El problema de si creo o no lo mismo cuando creo que las caras de la pirámide son equiláteras, que cuando creo que son equiángulas, sigue en pie después de negar la existencia del objeto de la creencia. En Word and Object sugiero que la pregunta de hasta donde puedo parafrasear una creencia, sin perder el derecho a criticarla, depende del propósito de la crítica. Esto puede generalizarse a todas las actitudes proposicionales. $\mathrm{Y}$, siendo así, no hay esperanza de una traducción general de las expresiones de actitudes proposicionales a términos más objetivos. Por eso estas expresiones se dejan a la lengua vernácula, y no tienen lugar en el austero aparato de la ciencia. Pero si al hacer esto con las palabras indicadoras no sentimos pérdida alguna, porque sabemos para qué sirven y cómo sustituirlas, con respecto a las expresiones de actitudes proposicionales sentimos una pérdida genuina. Nos gusta decir, por ejemplo, que el gato quiere subirse al tejado, o que teme que el perro le haga daño. Al decir esto, intentamos relacionar al gato quizá con un estado de cosas. $\mathrm{Y}$ no hay manera de evitar la relación con un estado de cosas. El deseo o el temor del gato no pueden encerrarse en ninguna descripción de su conducta ni tampoco en una descripción fisiológica. Las relaciones con estados de cosas nos proporcionan algunas formas especiales y al parecer indispensables de agrupar eventos en el mundo natural. Nuestras dificultades filosóficas vienen tal vez de la presuposición oracional de nuestras expresiones de actitudes proposicionales. Estas expresiones guardan la estructura de la cita indirecta y por tanto nos complican en el problema de los límites de la variación permisible de la oración subordinada. Este problema verbal parece ridiculamente irrelevante con relación a los mundos animales. ¿Podremos explicar algunos casos primitivos de actitudes proposicionales hablando de estados de cosas, en algún sentido del término que se distinga de proposición u oración? Comencemos entendiendo un estado de cosas como la clase de todos los mundos posibles en que se presente ese estado de cosas. Para simplificar las cosas aceptemos una física como la de Demócrito. Los átomos son homogéneos en sustancia y se diferencian solamente por su tamaño, forma, posición y movimiento. Supongamos al espacio euclideano. Para cada punto sólo caben dos posibilidades, el punto está dentro de un átomo o está vacío. Un estado momentáneo del mundo posible es una distribución de todos los puntos entre vacíos y llenos. Esto 
es como si tomásemos las descripciones de estado de Carnap con un solo predicado: 'ocupado'. Pero no es así. Una objeción a las des. cripciones de estado es que cada individuo debería tener su nom. bre. Pero nuestros individuos son todos los puntos del espacio y no son, por tanto, denumerables, cuando los nombres si lo son. Pero en nuestro caso un posible estado del mundo no es verbal, puede identificarse con el aggregatum de los puntos ocupados. Hasta aquí parecemos comprometidos a aceptar dos tipos de individuos: puntos y porciones materiales. Los puntos pueden eliminarse adoptando un sistema de coordenadas y reemplazarlos por triadas ordenadas de números reales. Nuestra ontología contaría con porciones de materia como individuos y la ordinaria superestructura de clases de individuos, clases de clases, etc. Un estado posible de mundo sería, según esto, una clase de triadas de números reales. Otra razón para preferir las triadas ordenadas 2 los puntos es la relatividad de la posición. Mientras no aceptemos que la posición absoluta tiene sentido, no podremos clasificar los puntos como entidades. Esta relatividad permanece en nuestro sistema de coordenadas, el mismo estado posible de mundo puede darse con diferentes triadas de números, gracias a rotaciones a translaciones de los ejes coordenados. Por ello convendría tomar un estado posible de mundo, no como una clase de triadas sino como una clase de clases de triadas, la clase de todas las clases de triadas que pudieran resultar de la translación o rotación de los ejes. 0 , dicho en términos de puntos, la clase de todas las clases de puntos congruentes con una clase dada. Así, nuestros estados posibles de mundo quedan libres del espacio absoluto y de la arbitrariedad de las coordenadas. Quedaría solamente la arbitrariedad de las unidades de medida. El cambio de pies a centímetros haría variar las clases de triadas. Una generalización semejante a la anterior nos evitaría esta relativización a las unidades de medición. Un estado posible de mundo sería la clase de todas las clases en las que una clase de triadas $C$ pueda ser convertida mediante el cambio de ejes y la multiplicación de todos los números por una constante. Dicho esto en lenguaje geométrico, tomamos un posible estado de mundo como la clase de todos los conjuntos de puntos geométricamente similares a un conjunto dado de puntos. Con esto hemos ganado, además, superar un concepto absoluto de tamaño. Pero esto podría ser demasiado. Supongamos que tiene sentido distinguir dos mundos cuya única diferencia consistiere en que uno mide el doble que el otro. Si esto fuese así, convendría volver a tomar un sistema de medida arbitrario. Estoy, sin embargo, en contra de esta posibilidad. Concedido, por ejemplo, que la masa absoluta juegue un papel en las leyes de la física que la posición 
absoluta no desempene, de todos modos podríamos declarar en todas partes un cambio en la masa absoluta, mediante un cambio sistemático en las leyes, que lo compensara. Esta maniobra combinada sigue siendo solamente verbal, de aquellas que llevan un estado de mundo posible solamente a sí mismo.

Un mundo posible sería explicado de la misma forma. Bastaría añadir una dimensión más: el tiempo. Sin embargo, encontraremos complicaciones nuevas provenientes del hecho de que la coor. denada temporal tiene unidades de medida independientes de las demás coordenadas. Recuérdese que nos encontramos en un sistema preeinsteiniano. Habremos, pues, de modificar la estipulación de similaridad geométrica en dos sentidos: la reforzamos prescribiendo que las cosas preserven su polarización con respecto a la cuarta dimensión; la relajamos permitiendo un estiramiento uniforme de la cuarta dimensión.

Lo que el gato quiere, entonces, es el estado de cosas equivalente a la clase de todos los mundos posibles en los que él esté en ese tejado. Lo que teme es la clase de todos los mundos posibles en los que le tiene el perro. Lo que creo es la clase de todos los mundos posibles en los que la gran pirámide tiene caras de equiláteras... El problema de la individuación que nos preocupaba con respecto a las proposiciones está resuelto satisfactoriamente con relación a los estados de cosas. Los mundos en los que las caras de las pirámides son equiláteras son, por cierto, los mundos en los que son equiángulas. Otra cosa que creo es la clase de todos los mundos posibles en los que Cicerón denuncia a Catilina. Tenemos, empero, nuevos problemas. ¿Cómo identificar a Catilina en los varios mundos posibles? ¿Tendrá que haber llevado el nombre de 'Catilina'? ¿Qué tanto podrá diferir su vida para ser considerado otra persona con el mismo nombre? Aún el caso del gato acarrea problemas. En un mundo posible con muchos gatos similares, perros y techos, ¿qué gato será él? Uno de esos mundos posibles tendrá un gato como él en un tejado como el suyo y otro gato como él en las fauces del perro. ¿Pertenece este mundo posible tanto al estado de cosas deseado como al temido? Estos ejemplos sugieren que me haya excedido al abstraer el emplazamiento de las coordenadas. Tal vez hubiera sido conveniente mantener el origen fijo y sólo permitir la rotación de los ejes. El sujeto de la actitud proposicional se identificaría como el organismo al origen. Esto arreglaría el caso del gato, aunque no solucionaría los ejemplos de la pirámide o de Catilina. Tenemos con el gato lo que podríamos llamar estados de cosas centrados. Cada uno sería la clase de posibles mundos centrados. Cada mundo posible centrado es la clase de todas las clases de tetradas numerales que pueden obtener- 
se de alguna clase de tetradas de números mediante la multiplica. ción de los primeros tres números por un factor constante, la multiplicación del cuarto número por una constante quizá distinta y llevando al cabo las operaciones correspondientes a la rotación de los primeros tres ejes. Así, sugiero que los objetos de las acti. tudes proposicionales sean tomados, en algunos casos primitivos, como estados de cosas centrados. Esto no cubre sino las actitudes proposicionales egocéntricas, aquellas como desear, esperar, temer o tratar de estar en algún tipo de situación física, es decir, las actitudes más primitivas. Son, tal vez, las únicas que el mundo animal podría decirse que sustenta, creo que las otras presuponen lenguaje.

Puede decirse, sin embargo, que si vamos a ocuparnos solamente con actitudes egocéntricas, los estados de cosas centrados abarcan demasiado territorio. Cuando un animal asume una actitud acerca de lo que podría herirlo o golpearlo, sólo tomaría en cuenta ciertas posibilidades de activación o inactivación de sus terminales nerviosas. En lugar de una distribución cósmica de decisiones binarias, debemos considerar una distribución de decisiones binarias sobre los receptores sensoriales del animal. Cada una de estas distribuciones es un mundo posible que llamaremos estructura de estímulo, para distinguirlas de los mundos posibles en e] sentido anterior. Entonces, como objeto de la actitudes proposio. nal podemos tomar el rango de estructuras de estímulos del propio gato, que constituirían su estar en el tejado.

Si se trata el lenguaje como un fenómeno natural, debemos co. menzar reconociendo que ciertos proferimientos están conectados con rangos de estructuras de estímulo sensorial. A estos rangos lla. mo significados de estímulo. Tenemos, empero, un problema: parece esencial que al correlacionar el comportamiento verbal de un sujeto con el de otro seamos capaces de equiparar los estímulos de ambos. Pero si construimos las estructuras de estímulo a mi manera, sólo podríamos equiparar unos con otros mediante la suposición de una homología en los receptores, lo que es absurdo, no sólo porque una completa homología sea imposible, sino porque seguramente no deberia importar. Es el estímulo de la superficie corporal el que cuenta y no sólo la existencia objetiva de los objetos distantes de referencia o los sucesos internos del cuerpo. Aún la madre primitiva al guiar al niño en el uso de cierta palabra, considerará si el objeto relevante está visible, no si existe. La madre civilizada no tratará de penetrar bajo la piel de su hijo. Sin embargo, cuando tratamos el aparente esencial problema de qué signifique que dos personas tengan el mismo estímulo, reapa. rece el mito de las terminaciones nerviosas homólogas. Este pro. 
blema es de un carácter eminentemente teórico. En la práctica averiguamos si dos sujetos tienen el mismo estímulo observando que sus cuerpos estén sometidos a las mismas fuerzas exteriores, que sus cuerpos estén orientados en la misma forma hacia las fuentes del estímulo y, tal vez, que sus ojos estén abiertos. En estos términos podríamos aún comparar a un hombre con un marciano, sin llegar a preocuparnos sobre homologías que vayan más allá de lo que tenga que saberse para orientar al marciano hacia las fuentes estimulantes. El marciano podría muy bien reaccionar a fuerzas frente a las que el hombre no responde y viceversa. La respuesta del receptor es lo que cuenta y es por esto que la equiparación de los estímulos de dos sujetos nos lleva a proponer consideraciones de homología cuando tratamos de hacer una teoría explícita. Nuestro procedimiento práctico funciona gracias a los parecidos anatómicos de la gente. Gracias a esas similaridades la lengua misma ha podido propagarse. 